\title{
MODEL KOMUNIKASI ARSITEKTURALIS SEBAGAI MEDIA DAKWAH
}

\section{Suharto Suharto}

email: lectorsuharto@gmail.com

Dosen Tetap Jurusan Komunikasi dan Penyiaran Islam IAIN Palu

\section{Abstract:}

This paper deals with the dynamic of the development of technology and information that dominate every public spheres particularly in urban areas today. Modernization of technology plays an important role in determining the development of information and communication either in its capacity as a science or applied science. A myriad of communication models emerge and develop in the phenomenon of communication itself which indicate that modernization of communication is a source of communication technology as applied science. At the same time, modernization of communication using technologies is a part of causing factors to integration of communication compounded with modern architecture. Therefore, it can be used as a medium of Islamic preaching.

$$
\begin{aligned}
& \text { ويحاول هذا البحث على تحليل دينامكية تطور التكنولوجيا والمعلومات التي تهيمن على كل ميادين }
\end{aligned}
$$

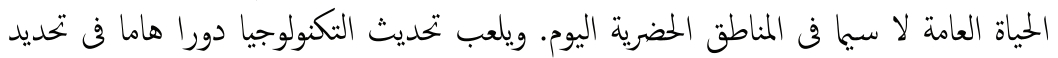

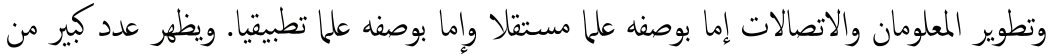

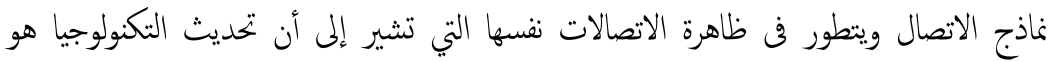

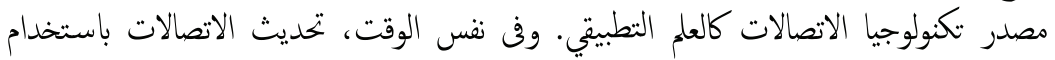

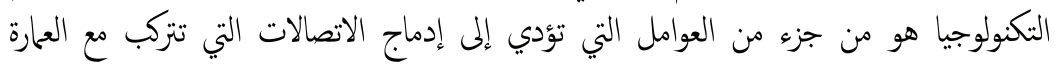

$$
\begin{aligned}
& \text { الحديثة. وبالتالي، فإنه يكن استخداما وسيلة للدعوة الإسلامية. . }
\end{aligned}
$$

Kata Kunci: komunikasi, arsitekturalis, media, dakwah 
Suharto Suharto, Model Komunikasi Arsitekturalis Sebagai Media Dakwah

\section{Pendahuluan}

Dalam beberapa tahun terakhir, pembicaraan luas tentang 'cyberspace' (jagat maya) telah membawa perhatian baru terhadap gagasan (sebagaimana yang ditulis oleh Meyrowitz (1999), dikutip oleh david Holmes) bahwa riset media kurang fokus pada pesannya dan lebih fokus pada teknologi komunikasi sebagai jenis-jenis lingkungan sosial. ${ }^{1}$

Secara mondial, modernisasi teknologi telah berperan sangat penting dalam menentukan perkembangan informasi dan komunikasi, baik dalam kapasitasnya sebagai sebuah disiplin ilmu pengetahuan maupun dalam konteks ilmu terapan. Sejalan dengan laju perkembangan teknologi tersebut, maka eksistensi dan pemanfaatan jagat maya atau cyberspace pun dapat dipastikan telah menjadi senyawa yang tak terpisahkan dengan teknologi pada setiap penataan ruang-ruang publik perkotaan secara arsitekturalis dan teknis.

Masyarakat perkotaan adalah inhern dengan masyarakat infomrasi (information society), lantaran teknologi informasi dan komunikasi sudah berakselerasi dengan beragam model yang semakin lengkap, cepat dan canggih. Secara gamblang dapat dipastikan bahwa akses informasi dan fasilitas komunikasi tidak lagi terbatas pada koran, majalah, radio, televisi, faximile, handytalky, telephone dan suratmenyurat. Juga, bukan lagi pemanfaatan handphone yang sebatas menelpon, SMS dan internet terbatas. Tetapi, akselerasi perkembangan teknologi informasi dan komunikasi kian memanjakan penggunanya dalam kehidupan keseharian kita dewasa ini. Penggunaan media sosial

${ }^{1}$ David Holmes, Teori Komunikasi: Media, Teknologi dan Masyarakat, Yogyakarta: Pustaka Pelajar, Cetakan I: 2012, h. 1 
(social media) yang berbasis internet dapat diakses kapan saja dan dimanapun serta dalam situasi apapun. Bahwa akses informasi tersebut sudah tidak terikat oleh ruang dan waktu, di rumah, di jalan, di kantoran dan dimana saja, informasi dan komunikasi dapat dimanfaatkan.

\section{Model Shanon dan Weaver}

Seperti dikutif di laman makalah Muhlys Ali seorang mahasiswa jurusan ilmu komunikasi yang membahas tentang teori Shanon dan Weaver ${ }^{2}$ bahwa Model adalah representasi suatu fenomena, baik nyata maupun abstrak, dengan menonjolkan unsur-unsur terpenting fenomena tersebut. Model jelas bukan fenomena itu sendiri. Akan tetapi, peminat komunikasi, termasuk mahasiswa, sering mencampuradukkan model komunikasi dengan fenomena komunikasi. Hanya saja model tersebut sekaligus mereduksi fenomena komunikasi artinya ada nuansa komunikasi lainnya yang mungkin terabaikan dan tidak terjelaskan oleh model tersebut ${ }^{3}$.

Teori matematikal ini acapkali disebut model Shannon dan weaver, oleh karena Teori komunikasi manusia yang muncul pada tahun 1949, merupakan perpaduan dari gagasan Claude E. Shannon dan Warren Eaver. Shannon yangpada tahun 1948 mengetengahkan teori matematik dalam komunikasi permesinan (engineering communication),

\footnotetext{
${ }^{2}$ Murti Kusuma Wirasty,

http://sevannisa.blogspot.co.id/2012/11/model-komunikasi-shannon-weaver.html diakses, 20 Mei 2015

${ }^{3}$ Muklys Ali, Makalah Mata Kuliah Ilmu Komunikasi: Model Shanon dan Weaver, http://mahasiswa.ung.ac.id/291413005/home/2014/1/30/
} 
Suharto Suharto, Model Komunikasi Arsitekturalis Sebagai Media Dakwah

yang kemudian bersama Warren pada 1949 diterapkan pada proses komunikasi manusia (human communication). Sejak itulah istilah komunikasi dipergunakan "dalam pengertian yang amat luas yang mencakup semua prosedur dimana pikiran seseorang mempengaruhi pikiran orang lain" (very broad sense to include all of the procedures by which on mind may affect another).

Model Shanon dan Weaver sering disebut model matematis atau model teori informasi itu mungkin adalah model yang pengaruhnya paling kuat atas model dan teori komunikasi lainnya. Shanon adalah seorang insinyur pada Bell Telephone dan ia berkepentingan dengan penyampaian pesan yang cermat melalui telepon. Weaver mengembangkan konsep Shanon untuk menerapkannya pada semua bentuk komunikasi.

Model Shannon dan weaver ini menyoroti problem penyampaian pesan berdasarkan tingkat kecermatannya. Model itu melukiskan suatu sumber yang menyandi atau menciptakan pesan dan menyampaikannya melalui suatu saluran kepada seorang penerima yang menyandi balik atau mencipta ulang pesan tersebut. Dengan kata lain, model Shannon dan weaver mengasumsikan bahwa sumber informasi menghasilkan pesan untuk di komunikasi atau (transmiter) mengubah pesan menjadi sinyal yang sesuai dengan saluran yang digunakan. Saluran (chanel) adalah medium yang mengirimkan sinyal (tanda) dari transmitter ke penerima (receiver). Dalam percakapan, sumber informasi ini adalah otak, transmiternya adalah mekanisme suara yang menghasilkan sinyal (katakata terucapkan), yang di transmisikan lewat udara (sebagai saluran). Penerima (receiver), yakni mekanisme pendengaran, melakukan operasi sebaliknya yang dilakukan transmitter dengan merekonstruksi pesan dari 
sinyal. Sasaran (destination) adalah (otak) orang yang menjadi tujuan pesan itu.

Konsep-konsep lain yang merupakan andil Shannon dan weaver adalah entropi (entropy) dan redundansi (redudancy) serta keseimbangan yang diperlukan diantara keduanya untuk menghasilkan komunikasi yang efisien dan pada saat yang sama mengatasi gangguan yang sama. Secara ringkas, semakin banyak gangguan, semakin banyak kebutuhan akan redundansi, yang mengurangi entropi relative pesan. Dengan menggunakan rendundansi yang mengatasi gangguan dalam saluran, jumlah informasi yang dapat di transmisikan tereduksi pada saat tertentu.

Model Shannon dan weaver dapat di terapkan kepada konteks konteks komunikasi lainya seperti komunikasi antar pribadi, komunikasi publik atau komunikasi masa sayangnya model ini juga memberikan gambaran yang parsial mengenai proses komunikasi. Lagi, komunikasi di pandang sebagai fenomena statis dan satu arah. Juga tidak ada konsep umpan balik atau transaksi yang terjadi dalam penyandian dan paenyandian balik dalam model tersebut ${ }^{4}$.

\section{Model Komunikasi Arsitekturalis}

Istilah model komunikasi arsitekturalis ini, merupakan cara pandang penulis terhadap dinamika perkembangan terknologi dan informasi yang menghiasi, mewarnai dan bahkan mendominasi setiap ruang-ruang publik (terutama) dalam wilayah perkotaan saat ini. Model komunikasi ini bukan sebuah hasil riset akademik dan hanya sebuah konklusi sementara sejenak penulis melihat, menyimak dan mengamati

${ }^{4}$ Ibid. 
Suharto Suharto, Model Komunikasi Arsitekturalis Sebagai Media Dakwah

setiap gerak langkah masyarakat kota yang dapat dikatakan bahwa media-media komunikasi tidak lagi fokus pada surat kabar, majalah, berita televisi, siaran radio dan sebagainya. Namun, penataan kota secara teknis dan arsitekturalis senantiasa dibarengi dengan cyberspace. Jagat maya atau 'cyberspace' tersebut tidak lagi sebatas spanduk, baligho, dan banner. Fenomena digitalisasi cyberspace tersebut ditata sedemikian rupa, baik dalam bentuk ukuran besar dan sedang dapat disaksikan berbagai berita, iklan dan pesan-pesan komunikasi lainnya secara cepat dan tertata baik, termasuk pengintegrasian gedung-gedung tinggi atau tower maupun perkantoran pemerintahan telah menggandeng cyberspace secara digitalisasi yang ditempatkan di bagian strategis di salah satu ruang terbuka pada bangunannya sehingga memudahkan setiap pengguna jalan yang melintas dapat memperoleh informasi tanpa harus beriklan di media sosial lainnya seperti koran, televisi dan radio.

Di kota-kota besar dan maju di Indonesia seperti Jakarta, Bandung, Semarang, Jogjakarta, Surabaya, Medan dan Makassar misalnya, komunikasi arsitekturalis sangat nampak dalam setiap desaindesain tata kota atau ruang-ruang publik maupun desain bangunan yang senantiasa memakai fasilitas layanan iklan digital yang pemanfaatannya diperuntukkan untuk publik yang berkepentingan terhadap media komunikasi untuk mensosialisasikan, menjual produk, membuat berita dan semacamnya, cukup dengan fasilitas tersebut maka akan memudahkan mengakses jaringan informasi yang lebih luas dan lebih cepat, baik dalam bentuk running text, maupun news update dan gambar.

Secara empiris, menurut Marco merujuk pada beberapa pakar telah menunjukkan bagaimana bentuk-bentuk teknologis tertentu dari broadcast massa telah berkurang atau terfragmentasi sehingga 


\section{$\Delta$ L-nish $\exists \bar{\Delta} H$ H, Vol. 11 No. 1, Januari-Juni 2015: 105-116}

mendukung market-specific-communication atau komunikasi yang spesifik pasar $^{5}$.

Dengan demikian, maka Model komunikasi arsitekturalis ini dapat dikatakan sebagai bagian dari ruang lingkup medium-medium komunikasi sebagai pertanda bahwa dominasi bentuk komunikasi broadcast seperti surat kabar, radio dan televisi telah bergeser pada model komunikasi yang interaktif, praktis dan teoritis. Arsitekturalisme komunikasi adalah sebuah model yang menempatkan dua obyek yang sama pentingnya, yakni informasi dan teknologi. Dimana pada penggunaan medium komunikasi arsitekturalis tersebut mengharuskan adanya desain-desain arsitektur dan pelibatan bentuk-bentuk teknologi untuk menciptakan suatu karya komunikasi yang menarik, tertata, dan menghentak calon audiensnya.

Model ini dapat digunakan oleh siapa saja, baik politisi, akademisi, birokrasi pemerintahan, enterpreneur, organisasi dan juga para da'i, mubaliiq ataupun ustadz sangat relevan dengan bentuk komunikasi arsitekturalis dalam menjalankan aktivitasnya, mengiklankan programnya, menjual jasanya, dan juga dapat berfungsi menjadi medium dakwah islamiah dalam melakukan pencerahan, iklan-iklan yang mendidik serta menyampaikan hal-hal yang sifatnya ta'muruuna bil-mak'ruf watanhawna anil-munkar.

\section{Media Dakwah}

Makna dakwah yang berasal dari bahasa arab, dari kata - دع- يدعو دعوة yang diartikan sebagai memanggil, mengajak, membujuk atau

${ }^{5}$ Marco dalam David Holmes, Teori...., h. 8 
Suharto Suharto, Model Komunikasi Arsitekturalis Sebagai Media Dakwah

mempengaruhi seseorang. Secara spesifik kata dakwah didefinisikan oleh beberapa pakar Ilmu Dakwah sebagai berikut;

Toha Yahya Umar mendefinisikan kata dakwah dengan "Mengajak manusia dengan cara bijaksana kepada jalan yang benar sesuai perintah Tuhan, untuk kemaslahatan dan kebahagian mereka di dunia dan di akhirat'. ${ }^{6}$

Syekh Ali Mahfuz juga mendefinisikan bahwa dakwah adalah "Mendorong manusia atas kebaikan dan mencegah dari kemungkaran guna mendapatkan kebahagiaan hidup di dunia dan di akhirat". "(Dari kondisi) Positif kekondisi yang lebih positif . ${ }^{7}$ Rasulullah pernah bersabdaberkaitan dengan definisi ini, yakni berbunyi:

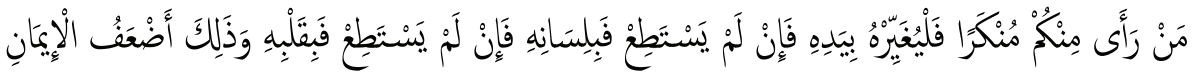
Artinya:

"Siapa di antara kamu melihat kemungkaran, ubahlah dengan tangannya, jika tidak mampu, ubahlah dengan lisannya, jika tidak mampu, ubahlah dengan hatinya, dan yang terakhir inilah selemahlemah iman".H.R. Muslim). ${ }^{8}$

Allah telah berfirman dalam Q. S. an.-Nnahl (16): 125, berbunyi:

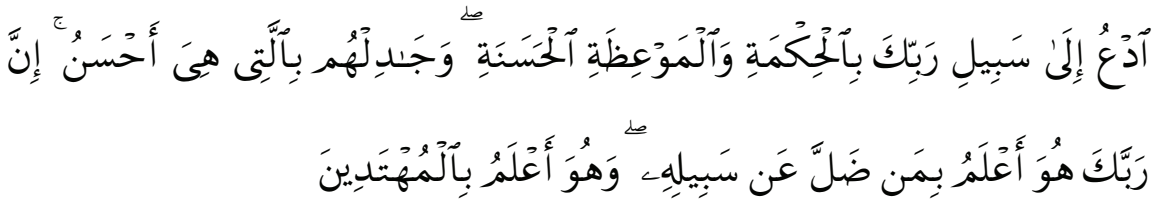

${ }^{6}$ Toha Yahya Umar, Ilmu Dakwah, (Cet. IV; Jakarta: Widjaya, 1985), h. 1

${ }^{7}$ Syekh Ali Mahfuz, Hidāyah Murshidīn ilā Turuqi an-Nāṣ wa AlkhaṬabah, (Beirut: Dār al-Ma'ārif, tth), h. 1

${ }^{8}$ Muslìm bin al-Hajjāj al-Qushairi, Șahị̣ Muslim; Bāb al-Imān, (Cet. 1; Beirut: Dar al-Fikr, 2003), h. 52 
Terjemahnya:

"Berdakwahlah kamu dijalan Allah dengan cara hikmah, dan nasehat yang baik dan berdebat dengan cara yang santun...". ${ }^{9}$

Dalam ayat lain Allah juga berfirman;

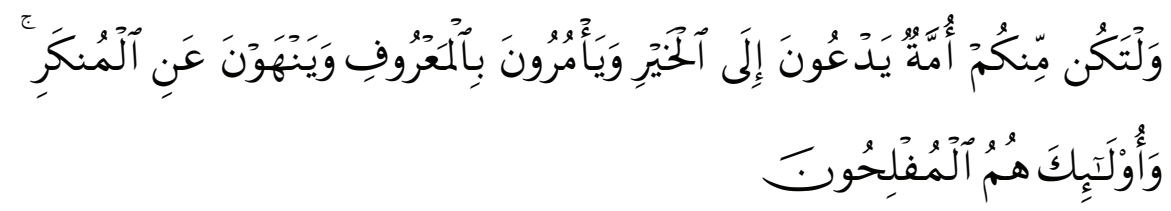

Terjemahnya:

"Jadilah kamu segolongan umat yang menyeru kepada kebajikan, menganjurkan pada yang ma'ruf dan mencegah kepada yang mungkar dan mereka itulah orang-orang yang beruntung." ${ }^{10}$

Dari definisi dan bunyi hadis dan ayat-ayat diatas yang mengandung perintah (amar) untuk berdakwah atau mengajak, membimbing seseorang atau manusia kepada kebaikan dan didalam berdakwah mengandung proses komunikasi. Maka secara esensil, berdakwah berarti berkomunikasi bahwa dakwah dan komunikasi samasama memiliki fungsi mendidik, menghibur, dan menginformasikan sesuatu kepada khalayak, atau mad'u atau audiens baik face to face, ataupun dalam bentuk massif dimana dakwah dapat dilangsungkan.

Persepsi seperti ini maka terjadi konseptualisasi komunikasi dakwah. Yakni aktivitas dakwah yang direncanakan ataupun yang akan dilangsungkan harus memenuhi prasyarat-prasyarat komunikasi seperti ada komunikan (da't), pesan (konten), sarana (media), mad'u (audiens) dan efek. 2010), h. 281

${ }^{9}$ Kementerian Agama RI, Alqurān dan Terjemahnya, (Bandung: Fokus Media, ${ }^{10}$ QS. Ali Imrān (3): 104. 
Suharto Suharto, Model Komunikasi Arsitekturalis Sebagai Media Dakwah

Secara singkat, komunikasi dakwah yang bertujuan untuk mengajak audiens agar senantiasa melakukan hal-hal yang baik dan menyeru agar menjauhi perkara-perkara kebathilan, kemungkaran dan semacamnya, sudah semestinya para muballig atau juru dakwah ataupun organisasi-organisasi yang menghimpun para da'i dapat melakukan terobosan-terobosan desain komunikasi dakwah yang lebih modern, kontemporer dan melibatkan atau berinteraksi dengan dunia maya (internet) untuk memanfaatkan fasilitas-fasilitas jejaring sosial (social networking), serta melakukan desain komunikasi dalam bentuk arsitekturalis.

Komunikasi dakwah arsitekturalis dimaksud adalah menciptakan medium dakwah yang high tecnology dan memanfaatkan ruang-ruang terbuka di bagian-bagian strategis di lingkungan masyarakat. Seperti pembentukan medium dakwah digital atau dakwah interface yang berteknologi tinggi berbasis internet.

Hal tersebut dapat memaksimalisasi program-program dakwah dalam mempercepat transformasi ayat-ayat Tuhan kepada jamaah sehingga dalam waktu singkat dan sangat cepat informasi-informasi dapat menyebar dan diakses secara luas secara gradual.

\section{Penutup}

Perkembangan mutakhir ihwal teknologi informasi dan komunikasi bukanlah perkara baru atau New Media ${ }^{11}$. Tetapi, modernisasi

${ }^{11}$ Untuk menjernihkan kebingungan yang disebabkan oleh apa yang disebut historisme New Media....... bukan sebagai pergeseran zaman tetapi sebagai tingkat integrasi komunikasi yang sebenarnya bukan baru sama sekali tetapi bersifat internal terhadap berbagai medium komunikasi yang telah ada berdampingan bersama broadcast jauh sebelum adanya internet. Lihat David Holmes, Ibid., h. 28. 
komunikasi dengan mempergunakan bentuk-bentuk teknologi adalah bagian sebab integrasi komunikasi yang bersenyawa dengan arsitekturalis modern.

Olehnya itu, tulisan mencoba menghadirkan antitesa terhadap urgensitas komunikasi arsitekturalis untuk dapat menjadi bagian dari model ilmu komunikasi. Yang penekanannya pada pemanfaatan ruangruang publik dan bangunan-bangunan arsitektur untuk mendesain sebuah medium komunikasi.

Model ini juga bukan hanya untuk mereka yang berprofesi sebagai politisi, birokrasi, pengusaha dan organisatoris. Tetapi semua steakholders masyarakat - terutama masyarakat perkotaan dapat memaksimalisasi sarana-sarana publik (public space) untuk menata sebuah media komunikasi. Termasuk para muballiq atau juru dakwah (komunikator dakwah), juga dapat mengintegrasikan bangun-rancang dakwahnya dengan model tersebut.

\section{Daftar Pustaka}

Arni Muhammad, DR. Komunikasi Organisasi, Jakarta: Bumi Aksara, 1989

Dewi, Sutrisna, Komunikasi Bisnis, Jogjakarta: Andi, 2006

Leliweri, Alo, Makna Budaya dalam Komunikasi Antar Budaya, Jogjakarta: LKiS, 2003

Holmes, David, Teori Komunikasi: Media, Teknologin dan Masyarakat, Yogyakarta: Pustaka Pelajar, Cetakan I: 2012 
Suharto Suharto, Model Komunikasi Arsitekturalis Sebagai Media Dakwah

Kementerian Agama RI, Alqurān dan Terjemahnya, Bandung: Fokus Media, 2010.

Muliana, Dedi, MA, Ph.D, Ilmu Komunikasi: Suatu Pengantar, Jakarta: Rosda, 2010

Mahfuz Syekh Ali, Hidāyah Murshidīn ilā Turuqi an-Nāṣ wa AlkhaTabah, Beirut: Dār al-Ma'ārif, tth.

al-Qushairi, Muslīm bin al-Hajjāj, Șahih Muslim; Bāb al-Imān, Cet. 1; Beirut: Dar al-Fikr, 2003.

Umar, Toha Yahya. Ilmu Dakwah, Cet. IV; Jakarta: Widjaya, 1985.

Murti Kusuma Wirasty

http://sevannisa.blogspot.co.id/2012/11/model-komunikasi-shannonweaver.html diakses, 20 Mei 2015 